\title{
Accumulation of an inactive form of p53 protein in cells treated with TNF $\alpha$
}

\author{
P Drané ${ }^{1}$, V Leblanc ${ }^{1}$, F Miro-Mur ${ }^{1}$, R Saffroy ${ }^{2}$, B Debuire ${ }^{2}$ \\ and $E$ May ${ }^{\star, 1}$ \\ 1 Commissariat à l'Energie Atomique (CEA), Laboratoire de Cancérogenèse \\ Moléculaire, UMR217 CEA-CNRS, DRR, DSV, BP6 92265 Fontenay-aux- \\ Roses Cedex, France \\ 2 Hôpital Paul-Brousse, Service de Biochimie et Biologie Moléculaire, Villejuif, \\ France \\ * Corresponding author: E May, Laboratoire de Cancérogenèse Moléculaire, \\ UMR217 CEA-CNRS, DRR, DSV CEA, 92265 Fontenay-aux-Roses Cedex, \\ France. Tel: 33 (0)1 465487 24; Fax: 33 (0)1 465487 13; \\ E-mail: may@dsvidf.cea.fr
}

Received 16.5.01; revised 24.10.01; accepted 13.11.01

Edited by M Oren

\begin{abstract}
In MCF-7 cells, TNF $\alpha$ induces a G1 arrest with an increased expression of p21/Waf1, an activation of NF- $\kappa$ B and an accumulation of $\mathrm{p} 53$. NF- $k \mathrm{~B}$ and $\mathrm{p} 53$ are two transcriptional factors known to activate p21/Waf1 gene expression. Here we show that p53 inhibition has no effect on p21/Waf1 mRNA accumulation following TNF $\alpha$ treatment. In contrast, inactivation of NF- $k$ B inhibits $p 21 /$ Waf1 expression without affecting G1 arrest. The fact that $p 21 /$ Waf1 gene expression is still stimulated when $p 53$ is inactivated strongly suggests that TNF $\alpha$ induces accumulation of an inactive form of $\mathrm{p} 53$ protein. This assumption was further supported by the following observations: (i) the p53 DNA-binding activity to its consensus sequence was not stimulated following TNF $\alpha$ treatment, (ii) phosphorylation at Ser-15, -20 or -392 was not detected in response to TNF $\alpha$, (iii) the transcription rate of $D d b 2$, another p53 target gene, was not stimulated by TNF $\alpha$. Finally, the accumulation of $p 53$ in the nuclei of TNF $\alpha$-treated MCF-7 cells was concomitant with an increase in p53 mRNA level, suggesting a regulation at the transcription level.

Cell Death and Differentiation (2002) 9, 527-537. DOI: 10.1038/ $\mathrm{sj} / \mathrm{cdd} / 4400983$
\end{abstract}

Keywords: p53; TNF $\alpha$; NF- $k B$; MCF-7; p53 activation

Abbreviations: HPV, human papilloma virus; NaSal, sodium salicylate; p53-DD, p53 dominant-negative; SOD2, superoxide dismutase 2; TNF $\alpha$, tumour necrosis factor-alpha

\section{Introduction}

To respond and adapt to changes in its external environment, such as exposure to growth factors, cytokines or stressinducing stimuli such as ionising radiation, the cell must initiate a program of regulated gene expression. This response depends on many factors such as the cell type and the number and intensity of the new stimuli. To a large extent these changes are mediated by nuclear DNA-binding proteins, which function in a combinatorial manner to activate or repress the transcription of target genes. Many cellular stimuli result in activation of both the tumour suppressor p53 and NF- $\kappa \mathrm{B}$.

$\mathrm{TNF} \alpha$ initiates a broad range of cellular responses including growth stimulation of various non-transformed cell lines (e.g. fibroblasts), and, in contrast, G1-growth arrest of many other transformed cell lines (e.g. the human breast carcinoma MCF-7) or apoptosis. ${ }^{1-4}$ At a molecular level, TNF $\alpha$ binds the TNF receptor and induces its trimerization. The ligand-bound activated TNF receptor associates with the cytoplasmic adaptor protein TRADD, which functions as a platform to recruit several signalling molecules (reviewed in $^{5}$ ). The active TNF receptor complexes can interact with caspase proteases via TRADD and FADD to induce apoptosis. ${ }^{6,7}$ TNF receptor complexes also interact, via TRADD, with TRAF2 and RIP proteins, which are involved in the activation of JNK/AP-1 and NF- $\kappa$ B. ${ }^{6-9}$ Different studies have shown that TNF-activated NF- $\kappa$ B plays an anti-apoptotic role against TNF cytotoxicity. ${ }^{10,11}$ In fact, NF- $\kappa$ B regulates a set of anti-apoptotic genes including members of the Bcl-2 family, cellular inhibitors of apoptosis protein (c-IAP2 and $c-I A P 1), A 20$ and superoxide dismutase 2 (SOD2) (reviewed in $^{12}$ ). Interestingly, $\mathrm{NF}-\kappa \mathrm{B}$ also regulates the expression of the tumour suppressor gene $p 53,{ }^{13}$ although the role of this regulation is not well understood. ${ }^{14,15}$

A large number of evidence places the p53 suppressor gene at a nodal point in the regulation of diverse stress responses. Indeed, a number of cellular stresses including DNA damage, heat shock, hypoxia, hyperoxia, metabolic changes, oncogene activation, and others, converge on p53 protein and cause its activation and stabilization. ${ }^{16}$ p53 is a transcription factor which exerts its function mainly through binding to a specific DNA responsive element. Activation of p53 by post-translational events (reviewed $i^{17}$ ) increases the affinity of the protein for its DNA consensus sites, leading to an increased expression of a set of target genes. Accumulation of the protein generally results from an extended half-life brought about by post-translational modifications that could be distinct from those involved in p53 activation. ${ }^{18}$ But accumulation of p53 could also arise from an up-regulation of its gene transcription rate. ${ }^{13}$

A number of p53-regulated genes are associated with induction of apoptosis or cell cycle arrest. ${ }^{19}$ One of the most important is the p21/Waf1 gene, an inhibitor of several cyclin-dependent kinases, and a target for diverse signals that induce growth arrest and differentiation. While p53 is not required for induction of $p 21 /$ Waf1 transcription during 
development and in most tissues of the adult mouse, the p53-dependent regulation of $p 21 /$ Waf1 is critical for the response to DNA damage (reviewed $\mathrm{in}^{20}$ ). Activation of p53 following exposure to DNA damage caused by UV- or $\gamma$ irradiation or chemotherapeutic agents leads to p53dependent transcription of p21/Waf1. Cells without functional p53 cannot induce p21/Waf1. ${ }^{21}$ However, there is accumulating evidence that the expression of the p21/Waf1 gene can be induced upon stimulation through a pathway, which does not require p53 (reviewed $\mathrm{in}^{20}$ ). Kobayashi et al. showed an increased rate and accumulation of p21/ Waf1 in TNF $\alpha$-treated cells expressing a transcriptioninactive p53 mutant. $^{22}$ In contrast, Jeoung et al reported that in MCF-7 cells induction of p21/Waf1 protein is closely related to p53 induction. Based on their results, they suggested that induction of $\mathrm{p} 21 / \mathrm{Waf} 1$ protein by TNF $\alpha$ is mediated by $553 .{ }^{4}$ By analyzing the response to TNF $\alpha$ of cell lines derived from MCF-7 and expressing either the
HPV E6 or DD protein, two p53 inhibitors, or $1 \kappa \mathrm{B} \alpha$, an inhibitor of $\mathrm{NF}-\kappa \mathrm{B}$, we provide evidence that $p 21 /$ Waf1 is not regulated by $\mathrm{p} 53$ but by NF- $\kappa \mathrm{B}$ in TNF $\alpha$-treated MCF-7 cells. This observation leads us to demonstrate that TNF $\alpha$ induces accumulation but not activation of $\mathrm{p} 53$.

\section{Results \\ Induction of p21/Waf1 gene expression in MCF-7 following TNF $\alpha$ treatment is independent of p53 expression}

In agreement with published data, ${ }^{23,24}$ results reported in Figure $1 \mathrm{~A}$ show that treatment of MCF-7 cells with TNF $\alpha$ $(10 \mathrm{ng} / \mathrm{ml})$ resulted in a transient arrest of cells at the G0/G1 phase followed by apoptosis. The cyclin-dependent kinase inhibitor p21/Waf1 is one regulator of the cell cycle that can cause cell growth arrest. ${ }^{25}$ Under our experimental conditions,

A
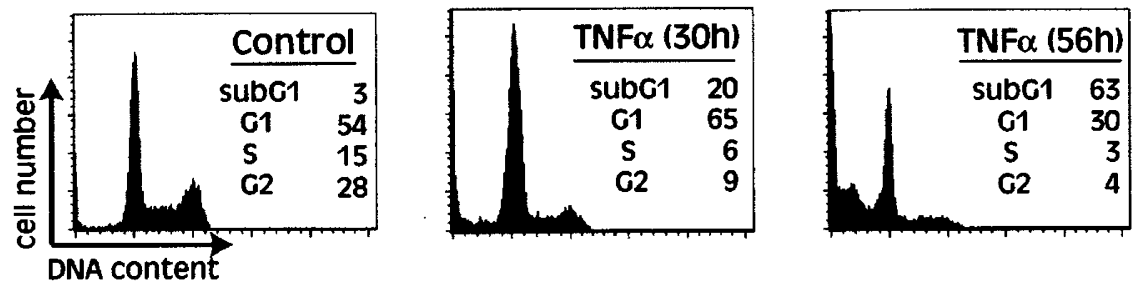

\section{B - Northern blot}

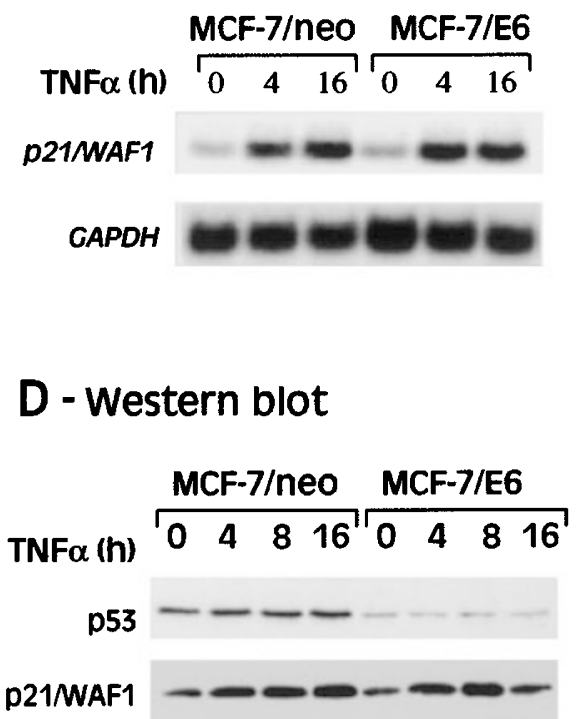

C - Quantitative RT-PCR

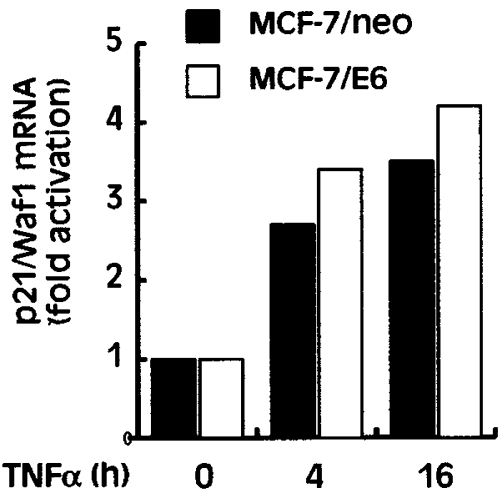

Figure 1 Effect of TNF $\alpha$ on MCF-7 cell cycle and p21/WAF1 gene expression. (A) TNF $\alpha$ induces a transient G1-growth arrest in MCF-7 cells. Cells were mocktreated (Control) or treated with TNF $\alpha(50 \mathrm{ng} / \mathrm{ml})$ for 30 and $56 \mathrm{~h}$. The DNA content was analyzed by flow cytometry. (B) and (C) TNF-induced p21/WAF1 mRNA accumulation is independent of $p 53$. MCF-7/neo and MCF-7/E6 cells were mock-treated or treated with TNF $\alpha$ for $4 \mathrm{~h}$ or $16 \mathrm{~h}$. Expression of $p 21 / W A F 1$ was analyzed by Northern blot (B) and by quantitative RT - PCR (C). (D) Expression of HPV/E6 in MCF-7/E6 cells prevents the accumulation of p53 protein in TNF $\alpha$-treated cells but is without effect on the increased expression of p21/Waf1. Following incubation with TNF $\alpha$ for the indicated times, volumes of cellular extract corresponding to $10 \mu \mathrm{g}$ of total proteins were loaded on a $10 \%$ (for p53 detection) or $12 \%$ (for p $21 /$ Waf1 detection) SDS-polyacrylamide gel and analyzed by Western blot using the antibodies D0-7 to reveal p53 and anti p21/Waf1 (Ab1 from Calbiochem) to reveal p21/Waf1 
p21/Waf1 mRNA was significantly increased by TNF $\alpha, 4 \mathrm{~h}$ after treatment (Figure 1B). These results corroborate those obtained by Jiang and Porter. ${ }^{24}$ Previous results have indicated that p53 accumulation preceded activation of p21/ Waf1 in response to TNF $\alpha^{4}$ suggesting a causal relationship between p53 activation, p21/Waf1 stimulation and G1 arrest. To test the possible implication of p53 in p21/Waf1 accumulation in TNF $\alpha$-treated MCF-7 cells, the induction of p21/Waf1 gene expression by TNF $\alpha$ was tested in MCF-7/E6, a MCF-7 derived cell line stably transfected with a cDNA encoding HPV16/E6 protein. ${ }^{26}$ Expression of E6 protein in MCF-7/E6 cells has been shown to impair the p53-dependent p21/Waf1 accumulation induced by $\gamma$-radiation. ${ }^{26}$ The viral protein E6 promotes p53 degradation by the ubiquitination pathway. ${ }^{27}$ This degradation accounts for the lower steadystate level of $\mathrm{p} 53$ protein in MCF-7/E6 as compared to MCF-7/ neo (Figure 1C, t0). This difference was enhanced following $\mathrm{TNF} \alpha$ treatment, which significantly increased the p53 protein level in MCF-7 cells but not in MCF-7/E6 cells (Figure 1C, t4 and 16). Unexpectedly, p21/Waf1 mRNA (Figure 1B and C) and protein (Figure 1D) levels were increased in TNF $\alpha$-treated MCF-7/E6 as strongly as in MCF-7/neo, suggesting that TNF $\alpha$ induces p21/Waf1 accumulation via a p53-independent pathway. To confirm these results, we established the MCF7/DD-TO cell line, a MCF-7 derived cell line engineered to exhibit a tetracycline inducible expression of p53DD, a dominant negative truncated p53 mutant. Two independent clones were analyzed in parallel. As already reported, ${ }^{28}$ the p53DD expression stabilizes MCF-7-endogenous wt-p53 (Figure 2A, lanes '+tet'), but inhibits its transcriptional activity as shown by transient expression of luciferase reporter gene under the control of a p53 responsive element (Figure 2B).

\section{A - Western blot}

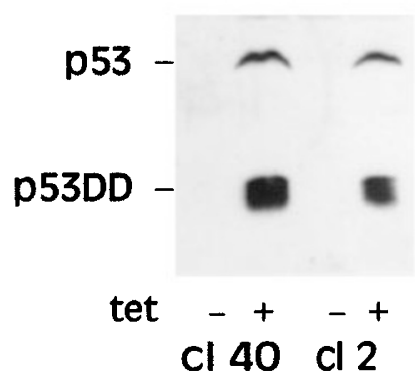

\section{C - Quantitative RT-PCR}

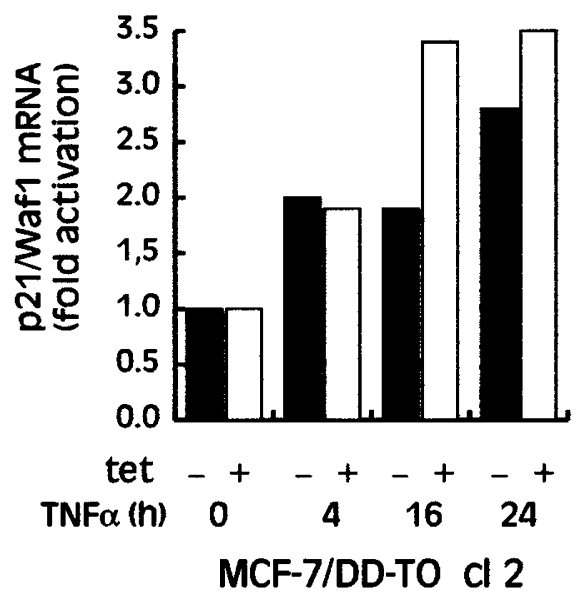

B - Luciferase assay

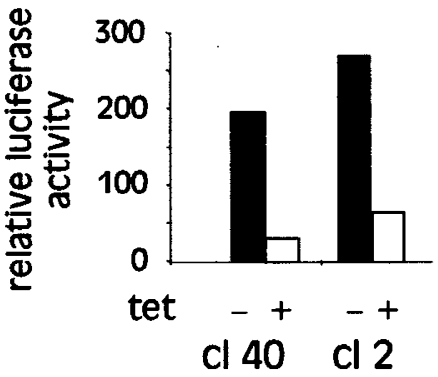

Figure 2 Inactivation of p53 by the truncated p53DD protein cells does not impair TNF $\alpha$-induced p21/WAF1 gene expression. MCF-7/DD-TO cell line expresses the p53-DD cDNA under the control of a Tet-on promoter. Clones 2 and 40 are two clones isolated independently. Tetracycline ( $1 \mu \mathrm{g} / \mathrm{ml}) \mathrm{was}$ added $24 \mathrm{~h}$ after cel plating (tet+). Non tetracycline exposed cells (tet-) were treated in parallel. (A) Tetracycline induces the expression of p53DD protein. p53DD expression was evaluated by Western blot using PAb122, $24 \mathrm{~h}$ after the addition of tetracycline. (B) Induction of p53DD expression impairs the p53 transactivation function. Six hours after the addition of tetracycline, the cells were transiently transfected with the luciferase reporter gene put under the control of the $\mathrm{p} 53$ responsive element of the human Waf1 promoter ( $\mathrm{pE} 1 \mathrm{~B}-\mathrm{hWaf1}$ ). Parallel cultures were transfected with a control plasmid that includes the luciferase reporter gene but not the p53 responsive element. Luciferase activity was measured after an additional incubation of $24 \mathrm{~h}$ with (+tet) or without (-tet) tetracycline. Results are expressed relative to those obtained with the control plasmid. (C) Inactivation of p53 by p53DD does not affect TNF $\alpha$-induced p21/WAF1 expression. Tetracycline (tet+) was added, or not (tet-) $4 \mathrm{~h}$ before the addition of TNF $\alpha$. Total RNA was extracted at the indicated time following TNF $\alpha$ addition. p21/WAF1 mRNA levels were evaluated by quantitative RT-PCR. Results are expressed as fold activation relative to non-TNF $\alpha$-treated cells in the absence and in the presence of tetracycline, respectively 
However, the p53DD expression (Figure 2C, lanes '+tet') had no effect on the increase of $p 21 /$ Waf1 mRNA level brought by $\mathrm{TNF} \alpha$ treatment. These results further support the assumption that TNF $\alpha$ stimulates the $p 21 /$ Waf1 gene expression by a p53independent pathway.

\section{p21/Waf1 expression is regulated by NF- $\kappa B$ in response to TNF $\alpha$}

In response to diverse signals that induce growth arrest and differentiation, p21/Waf1 is regulated at a transcription level by a number of distinct transcription factors, besides p53 $\left(\right.$ reviewed $\mathrm{in}^{20}$ ). Recently it was shown that, in TNF $\alpha$-treated Ewing tumour cells, the stimulation of $p 21 /$ Waf1 expression is dependent on NF- $\kappa \mathrm{B}$ activation. ${ }^{29}$ We then asked whether, in TNF $\alpha$-treated MCF-7 cells, the NF- $\kappa$ B activation could account for the p53-independent stimulation of p21/Waf1.

Under our experimental conditions, NF- $\kappa \mathrm{B}$ was already strongly induced in the $15 \mathrm{~min}$ following $\mathrm{TNF} \alpha$ addition to MCF-7 (Figure $3 \mathrm{~A}$ ) and this activation was prolonged for at least $16 \mathrm{~h}$ (Figure 6B, middle panel). We then analyzed, in both MCF-7 and MAD-1904, the effect of 4- and 16-h TNF $\alpha$-treatment on $p 21 /$ Waf1 mRNA expression. MAD1904 is a stable transformant of MCF-7 expressing the $\mathrm{I}_{\kappa} \mathrm{B} \alpha(\mathrm{A} 32 / 36)$ mutant, a superrepressor form of $\mathrm{I}_{\kappa} \mathrm{B} \alpha^{30}$

A

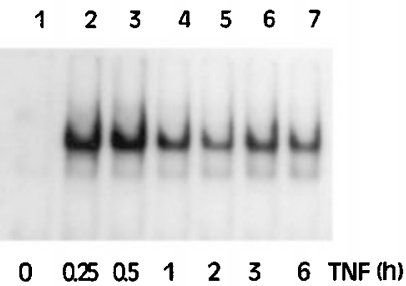

B

C
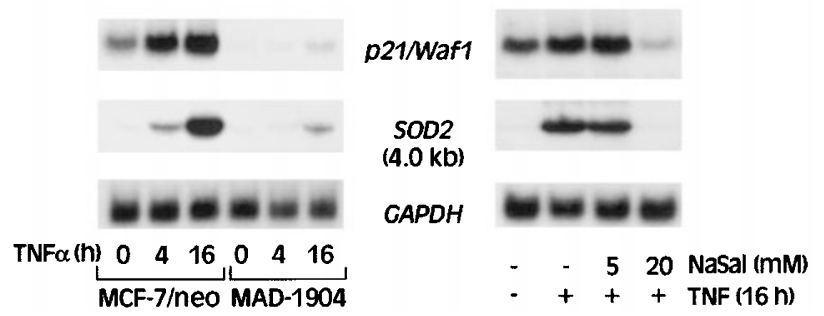

Figure 3 TNF $\alpha$ induces $p 21 / W A F 1$ expression via NF- $\kappa$ B. (A) Time-course analysis of NF- $\kappa \mathrm{B}$ activation following TNF $\alpha$ treatment. MCF-7 cells were incubated with $\mathrm{TNF} \alpha$ for the indicated times. DNA-binding activity of NF- $\kappa \mathrm{B}$ was then analyzed by EMSA, using the NF- $\kappa$ B consensus DNA-binding site from Promega. (B) The induction of $p 21 / W A F 1$ and SOD2 gene expression following TNF $\alpha$ treatment is impaired in MAD1904 cells. Total RNA was extracted from MCF-7/neo and MAD1904 cells either mock-treated or treated with TNF $\alpha$ for $4 \mathrm{~h}$ or $16 \mathrm{~h}$ before RNA extraction. Twenty $\mu \mathrm{g}$ of RNA were electrophoresed in $1 \%$ agarose- $6 \%$ formadehyde gel and transferred to nylon membrane (Hybond N, Amersham) by electrophoresis. The blot was successively hybridized with p21/WAF1, SOD2, and GAPDH cDNA probes. (C) Sodium salicylate (NaSal) abrogated the TNF $\alpha$-mediated stimulation of p21/WAF1 gene expression. MCF-7 cells were mock-treated or treated with the indicated amount of $\mathrm{NaSal}$. After $30 \mathrm{~min}$ of incubation, cells were mocktreated or treated with $10 \mathrm{ng} / \mathrm{ml} \mathrm{TNF} \alpha$ for $16 \mathrm{~h}$. p21/WAF1, SOD2 and GAPDH expression was analyzed as described in $\mathrm{B}$ which behaves like a constitutive repressor of $\mathrm{NF}-\kappa \mathrm{B}$ activity. ${ }^{31}$ SOD2 gene that is known to be regulated by $\mathrm{TNF} \alpha$ through an intronic NF- $\kappa \mathrm{B}$ element, ${ }^{32}$ was used as a positive control. ${ }^{33}$ As expected, TNF $\alpha$ treatment significantly increased the level of SOD2 mRNA in MCF-7 but not in MAD-1904 (Figure 3B). Similarly, p21/Waf1 expression was severely impaired in MAD-1904 cells, strongly suggesting that NF- $\kappa \mathrm{B}$ activation accounts for the upregulation of $p 21 /$ Waf1 gene expression in MCF-7 cells in response to TNF $\alpha$-treatment. To reinforce this assumption further, NF- $\kappa \mathrm{B}$ was inactivated using a chemical inhibitor, sodium salicylate (NaSal). ${ }^{34}$ A 30-min pre-incubation of MCF-7 cells with $5 \mathrm{mM}$ or $20 \mathrm{mM} \mathrm{NaSal}$ was followed by a 16-h incubation with TNF $\alpha$. As shown in Figure 3C, $20 \mathrm{mM}$ NaSal abrogated the TNF $\alpha$-induced SOD2 expression and both the endogenous and TNF $\alpha$-induced expression of $p 21 /$ Waf1, showing that NF- $\kappa \mathrm{B}$ does account for the TNF $\alpha$ dependent up-regulation of p21/Waf1 in MCF-7 cells. These results confirm and extend to MCF-7 those obtained by Javelaud et al., ${ }^{29}$ showing that in MCF-7, like in Ewing tumour cells, the regulation of $p 21 /$ Waf1 transcription depends on NF- $\kappa \mathrm{B}$. A functional NF- $\kappa \mathrm{B}$ binding site within the p21/Waf1 gene remains to be identified to prove definitely that the $p 21 /$ Waf1 gene is directly transactivated by $\mathrm{NF}-\kappa \mathrm{B}$.

\section{TNF $\alpha$-dependent G1-arrest is independent of NF- $\kappa$ B activation}

To examine further the implication of NF- $\kappa \mathrm{B}$-mediated activation of $p 21 /$ Waf1 gene expression in TNF $\alpha$-induced G1 arrest, the percentage of cells in $\mathrm{G} 1$ was evaluated comparatively by flow cytometry in both MCF-7/neo and MAD-1904 cells. Cells were treated in parallel with a mitotic inhibitor, the nocodazole. ${ }^{35}$ This allows identification of the true G1-arrest cell population (cells unable to proceed through S-phase) as illustrated in Figure $4 \mathrm{~A}$ by comparing panels $\mathrm{A} 1$ versus $\mathrm{A} 4$, and $\mathrm{B} 1$ versus $\mathrm{B} 4$. Addition of nocodazole to the culture medium considerably increases the G2/M peak. But, in MCF-7 TNF $\alpha$-treated cells there is only a modest increase in G2/M peak in the presence of nocodazole (Figure 4A, compare panels $A 3$ and $A 4)$. This result clearly illustrates the TNF $\alpha$-induced $\mathrm{G} 1$ arrest. This $\mathrm{G} 1$ arrest is equally observed with MAD-1904 (Figure 4A, compare panels A6 and A8), suggesting that TNF $\alpha$-specific $\mathrm{G} 1$ arrest is not dependent on NF- $\kappa \mathrm{B}$-mediated induction of $p 21 /$ Waf1 gene expression. This conclusion was further supported by analyzing the levels of p21/Waf1 protein comparatively in MCF-7/neo and MAD-1904. As expected, the extent of p21/ Waf1 protein accumulation in TNF $\alpha$-treated MCF-7/neo cells is not affected by nocodazole treatment (Figure 4B, compare lanes 3 and 4). Moreover, and in agreement with the inactivation of NF- $\kappa$ B in MAD-1904 cells, the p21/Waf1 protein level was very low in this cell line (Figure $4 \mathrm{~B}$, lanes 5 to 8 ) as compared to MCF-7/neo cells (Figure 4B, lanes 1 to 4 ).

\section{p53 is not activated by $\mathrm{TNF} \alpha$}

The fact that $p 21 /$ Waf1 gene expression is not stimulated by p53 in response to TNF $\alpha$ in MCF-7 strongly suggests that the 
A
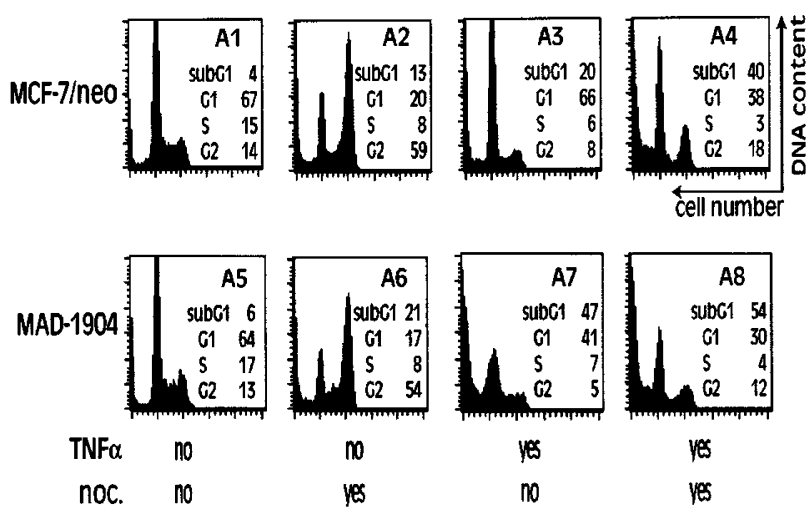

B

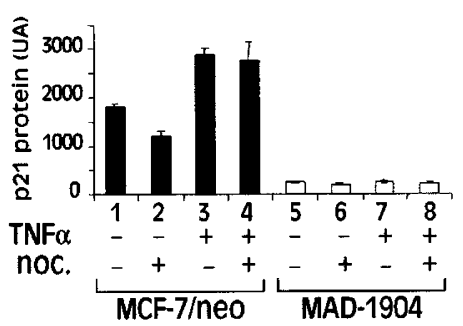

Figure 4 TNF $\alpha$-induced $\mathrm{G} 1$ arrest is independent of NF- $\kappa$ B. (A) MCF-7/neo (upper panels, A1 to A4) and MAD1904 (lower panels, A5 to A8), cells were mock-treated (panels $A 1, A 2$ and $A 5, A 6$ ) or treated with $10 \mathrm{ng} / \mathrm{ml}$ of TNF $\alpha$ (panels A3, A4 and A7, A8). For the cells treated with nocodazole (panels A2, $\mathrm{A} 4$ and $\mathrm{A} 6, \mathrm{~A} 8), 0.6 \mu \mathrm{g}$ of this drug was added $16 \mathrm{~h}$ before collecting the cells. The cultures were collected $40 \mathrm{~h}$ after the addition of TNF $\alpha$. DNA content was analyzed by flow cytometry. (B) p21/WAF1 protein levels were evaluated by ELISA in cultures treated in parallel. Results are expressed as Arbitrary Units (AU)

increase in p53 protein level is not concomitant with its activation. To further support this assumption, the effect of TNF $\alpha$ on p53-transcriptional activity was checked by analyzing the expression of $D d b 2$, a recently identified p53 target gene that encodes for the $\mathrm{p} 48$ subunit of a human damagespecific DNA binding protein. ${ }^{36}$ As expected, Ddb2 expression is stimulated in response to $\gamma$ irradiation in MCF-7/neo but is not in MCF-7/E6 cells. Yet, the expression of this gene is not stimulated in response to TNF $\alpha$ treatment (Figure 5), showing again that TNF $\alpha$-mediated induction of p53 gene expression is not accompanied by its transcriptional activation. To better understand the lack of p53-target gene stimulation following the induction of wt-p53 accumulation in TNF $\alpha$-treated MCF-7 cells, the affinity of p53 for its DNA responsive element was measured by electromobility shift assays (EMSA). Nuclear extracts of MCF-7 cells, mock-treated or treated with $10 \mathrm{ng} / \mathrm{ml}$ of $\operatorname{TNF} \alpha$ for $1.5,3$ and $16 \mathrm{~h}$, were incubated with doublestrand DNA sequences containing a binding site either for p53, NF- $\kappa$ B or Sp1 transcription factors. The p53 binding site used consists in a perfect p53 DNA responsive element, with two adjacent consensus decamers (Pu Pu Pu C A/T T/A Py Py Py). Adriamycin was used as a positive control for p53 activation. As expected, an intense band corresponding to the complex [DNA/p53/PAb421] was obtained with adriamycin-

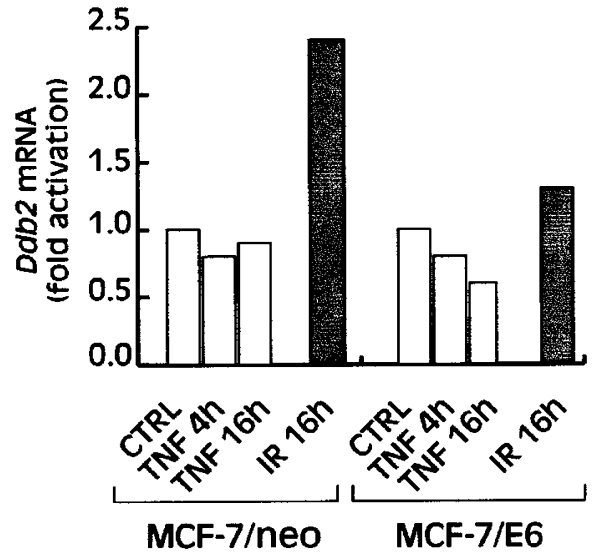

Figure 5 The p53-target gene Ddb2 is not stimulated by TNF $\alpha$. MCF-7/neo and MCF-7/E6 cells were incubated with $10 \mathrm{ng} / \mathrm{ml}$ of TNF $\alpha$ for the indicated times or irradiated at $6 \mathrm{~Gy}$ and incubated for an additional $16 \mathrm{~h}$ period. Expression of $D d b 2$ was analyzed by quantitative RT-PCR. Results were expressed as fold-stimulation relative to non-treated cells (CTRL)

treated MCF-7 cellular extracts (Figure 6B, upper panel, lane $5)$. In contrast, there was no apparent stimulation of p53specific DNA-binding activity following $\mathrm{TNF} \alpha$ treatment, irrespective of the treatment duration (Figure $6 \mathrm{~B}$, upper panel, compare lane 1 with lanes 2, 3, and 4). On the contrary, and in agreement with published data, ${ }^{37}$ both adriamycin and TNF $\alpha$ activated the specific DNA-binding activity of NF- $\kappa$ B (Figure $6 \mathrm{~B}$, middle panel, compare lane 1 to lanes 2, 3, 4 and 5). The Sp1 binding activity that was stimulated neither by adriamycin nor by TNF $\alpha$ treatment was used as a negative control (Figure $6 \mathrm{~B}$, bottom panel). To insure that the difference in p53-specific DNA binding activity of cellular extracts treated either with adriamycin or TNF $\alpha$ did not simply reflect a lower level of p53 accumulation in TNF $\alpha$ - versus adriamycin-treated cells, p53 concentration was evaluated by an ELISA assay. Indeed, the p53 concentration was increased by a factor 8 in adriamycin treated-cells and by only a factor 2 in TNF $\alpha$-treated cells (data not shown and Figure 8). DNA band-shift assay was then repeated by adjusting the volume of adriamycin- and TNF $\alpha$ treated cellular extracts to have an equivalent amount of p53 in each DNA-binding reaction mixture. Results presented in Figure 6, show a significant activation of p53-specific DNA binding activity in adriamycin-treated cellular extract even with a p53 concentration equivalent to that of untreated or TNF $\alpha$ treated cellular extracts (panel C2, compare lanes 1 and 2 to lane 3). From these results, we conclude that TNF $\alpha$ is not able to activate the MCF-7-endogenous wt-p53. This observation was extended to two other cell lines derived from tumours of different origins, but expressing wild-type p53. Similarly to the results obtained with MCF-7, TNF $\alpha$ did not activate specific DNA binding activity of the endogenous wt-p53 expressed either in Hep G2, a cell line derived from a hepatocellular carcinoma (Figure 6B, upper panel, compare lane 6 with lanes 7, 8, and 9), or in U-2 OS, a cell line derived from an osteosarcoma (Figure 6B, upper panel, compare lane 11 with lanes 12, 13, and 14). These results demonstrated that the specific DNA-binding activity of wt-p53 is not stimulated by $\mathrm{TNF} \alpha$, at least in the three cell lines tested. 


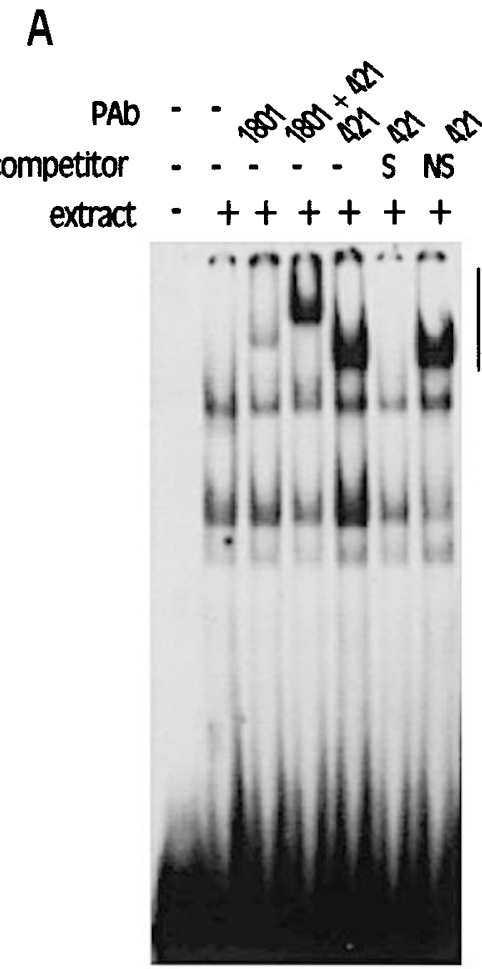

$\begin{array}{llllllll}1 & 2 & 3 & 4 & 5 & 6 & 7\end{array}$
B

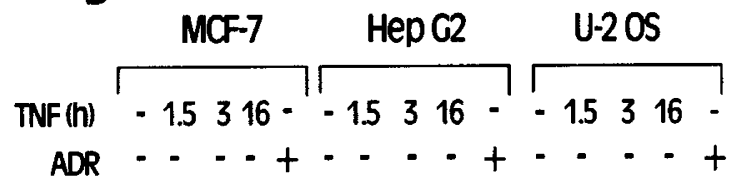

p53/PAb

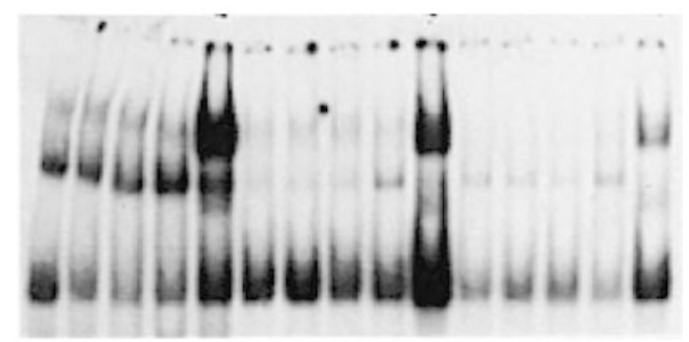

NF-kB

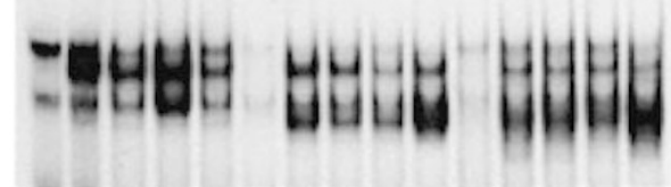

Sp1

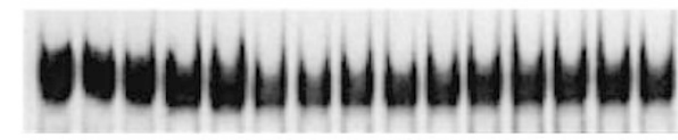

$\begin{array}{llllllllllllllll}1 & 2 & 3 & 4 & 5 & 6 & 7 & 8 & 9 & 10 & 11 & 12 & 1314 & 15\end{array}$
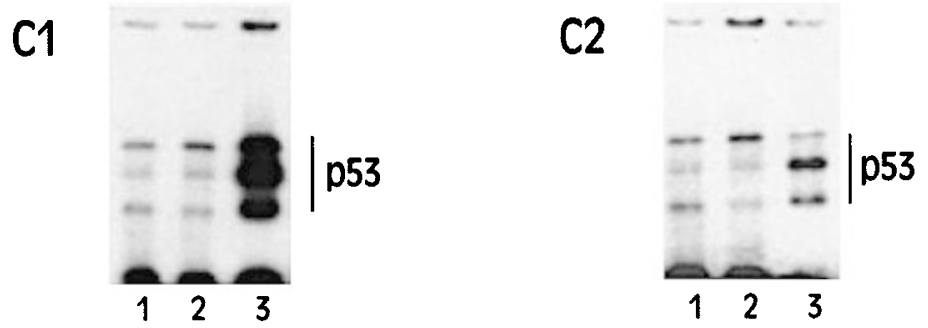

Figure 6 DNA-binding activity of p53 is not stimulated by TNF $\alpha$. (A) p53 expressing in MCF-7 is able to bind its responsive element. MCF-7 cells were incubated for $16 \mathrm{~h}$ with adriamycin $(10 \mu \mathrm{g} / \mathrm{ml})$. DNA binding activity of p53 was analyzed by EMSA. Nuclear extract (10 $\mathrm{g}$ of total protein) was incubated with ${ }^{32} \mathrm{P}$-labelled p53consensus binding site (lane 2) and with PAb1801 antibody (lane 3), a mixture of PAb421 and PAb1801 antibodies (lane 4), PAb421 antibody alone (lanes 5, 6 and 7). The specificity of the DNA binding was checked by adding $50 \times$ molar excess of either specific (S, lane 6 ) or non-specific (NS, lane 7) cold oligonucleotides. The vertical bar on the right of the figure indicates the migration position of either supershifted (DNA bound by PAb1801/p53 or PAb421/p53 molecules) or supersupershifted (DNA bound by PAb1801/PAb421/p53 molecules) specific complexes. (B) No stimulation of p53 DNA-binding activity in three TNF $\alpha$-treated cell lines expressing wt-p53. MCF-7 (lanes 1-5), Hep G2 (6-10) and U-2 OS (lanes 11-15) cells were incubated with $10 \mathrm{ng} / \mathrm{ml}$ of TNF $\alpha$ for the indicated times or with $10 \mu \mathrm{g} /$ $\mathrm{ml}$ of adriamycin (ADR) for $16 \mathrm{~h}$. DNA-binding activity of cellular extract was analyzed by EMSA with p53 (upper panel), NF- $\kappa \mathrm{B}$ (middle panel) and Sp1 (lower panel) specific DNA-binding sites. The vertical bar on the left of the figure indicates the migration position of specific shifted complexes. (C) Analysis of p53-specific DNA binding activity with equivalent amount of whole p53 expressed in cells treated with either TNF $\alpha$ or adriamycin. MCF-7 were non-treated (lane 1) or treated with TNF $\alpha$ (lane 2) or adriamycin (lane 3) as described in (B). DNA binding activity of p53 was analyzed on a PhastGel gradient 4-15\% (Amersham Pharmacia biotech). Binding assays were performed with $10 \mu \mathrm{g}$ of total proteins of each extract (C1) or with a volume of cellular extract adjusted to have the same amount of p53 protein (C2). The p53 concentration was estimated by ELISA. Binding assays were performed with a volume of cellular extract corresponding to 10 (C2, lane 1), 5 (C2, lane 2) or 1.25 (C2, lane 3) $\mu \mathrm{g}$ of total proteins

\section{p53 accumulates within the nuclei of TNF $\alpha$-treated cells}

Nuclear localization of $p 53$ has been shown to be essential for the activity of p53 protein. ${ }^{38}$ In normal, non-stressed cells, p53 sub-cellular localization is variable and depends on the phase of the cell cycle. p53 is predominantly nuclear from approximately mid $\mathrm{G} 1$ to $\mathrm{G} 1 / \mathrm{S}$ transition, then becomes increasingly cytoplasmic as the cell progresses through the cell cycle. ${ }^{39}$ Similar regulation of p53 intracellular localization through the cell cycle progression has been described for MCF-7. ${ }^{40}$ We then checked if p53 nuclear exclusion could account for the accumulation of an inactive form of p53 in cells treated with TNF $\alpha$. TNF-treated or untreated MCF-7 cells were subjected to cell fractionation, and p53 protein contents in both nuclear and cytoplasmic fractions were evaluated by 
Western Blot. Results are presented in Figure 7A. p53 protein was not detectable in mock-treated cells, nor in the cytoplasmic or nuclear fractions. As expected, p53 accumulated in the nuclei of $\gamma$-irradiated cells. Comparable results were obtained in response to TNF $\alpha$ treatment. A p53 band was easily detectable in the nuclear but not in the cytoplasmic fraction of cells incubated in the presence of TNF $\alpha$ for 4 and $16 \mathrm{~h}$. We conclude that nuclear exclusion cannot account for the fact that $p 53$ is transcriptionally inactive in TNF $\alpha$-treated cells.

\section{TNF $\alpha$ treatment does not induce p53 phosphorylation at Ser-15, -20 and -392, in MCF-7 cells}

The C- and N-terminal domains are exposed to covalent posttranslational modifications (phosphorylation, acetylation, sumoylation) that modulate p53 activity (reviewed $\mathrm{in}^{17,41}$ ). In particular, depending on the stress, phosphorylation at Ser-15 and -20 in the N-terminal region and -392 in the C-terminal
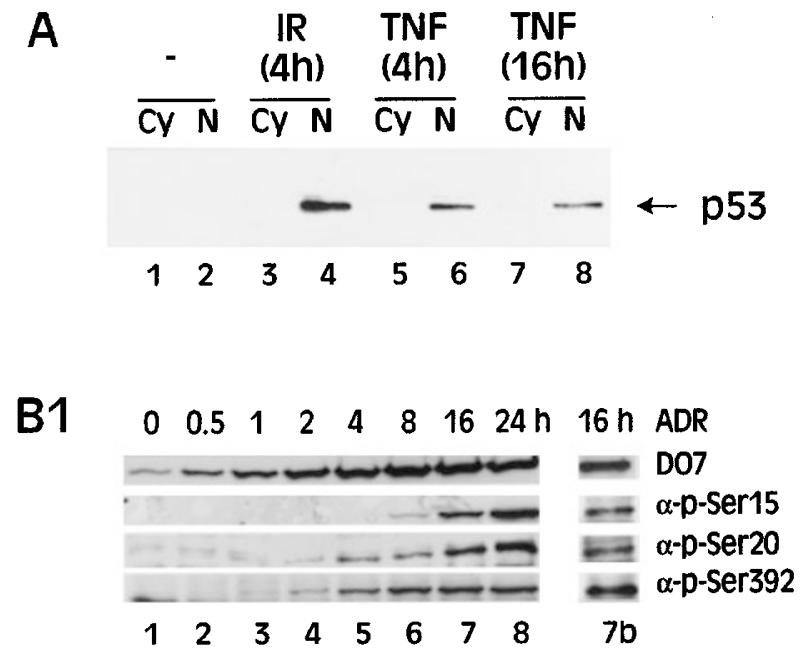

B2

$\begin{array}{llllllllllll}0 & 0.5 & 1 & 2 & 4 & 8 & 16 & 24 \mathrm{~h} & 16 \mathrm{~h} & \mathrm{TNF} \alpha\end{array}$

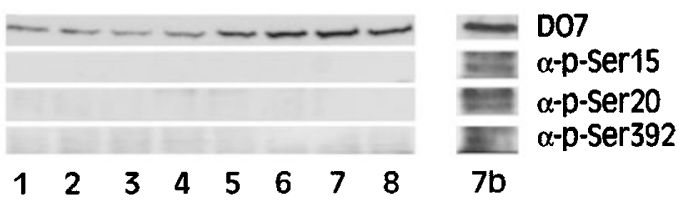

Figure 7 Intracellular localization and phosphorylation status of p53 in TNF $\alpha$ treated cells. (A) p53 accumulates in the nucleus of MCF-7 cells in response to TNF $\alpha$. MCF-7 cells were mock-treated (lanes 1,2), exposed to $\gamma$-radiation at a dose of 6 Gy for $4 \mathrm{~h}$ (lanes 3,4 ) or treated with TNF $\alpha$ for $4 \mathrm{~h}$ (lanes 5,6 ) or $16 \mathrm{~h}$ (lanes 7,8 ). Following treatment, cells were fractionated. Relative levels of p53 within the cytoplasm (Cy) and nuclear (N) fractions were evaluated by Western blot using anti-p53 DO-7 antibody. (B) Time course of p53 expression and phosphorylation at Ser-15, Ser-20 and Ser-392 in MCF-7 cells following adriamycin (B1) or TNF $\alpha$ (B2) treatment. MCF-7 cells were treated with adriamycin $(10 \mu \mathrm{g} / \mathrm{ml})$ or with TNF $\alpha(10 \mathrm{ng} / \mathrm{ml})$ for the indicated time. A volume of cellular extract corresponding to $60 \mu \mathrm{g}$ (B1 and B2, lanes 1 to 8$), 30 \mu \mathrm{g}$ (B1, lane $7 \mathrm{~b}$ ) or $90 \mu \mathrm{g}$ (B2, lane $7 \mathrm{~b}$ ) of total proteins was separated on a $10 \%$ SDS PAGE and analyzed by Western blot using specific antibodies as indicated

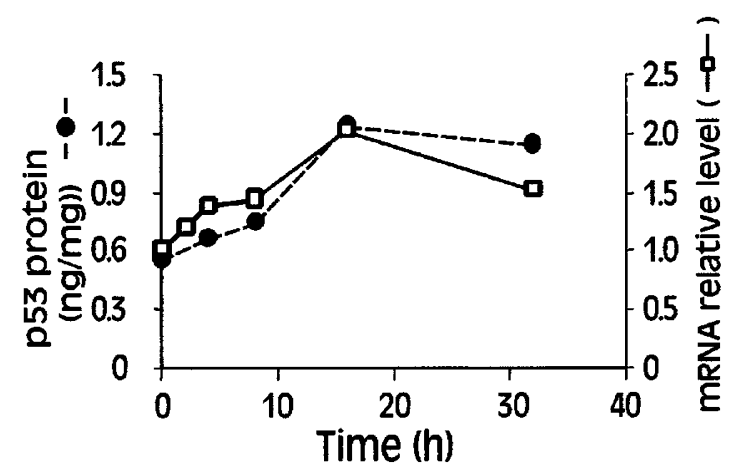

Figure 8 TNF $\alpha$ induces $p 53$ accumulation at both mRNA and protein levels. MCF-7 cells were incubated for different times with $10 \mathrm{ng} / \mathrm{ml}$ of TNF $\alpha$. p53 protein level was evaluated by ELISA (solid circle) and mRNA was quantified by RT-PCR (open square) as described in Materials and Methods

region participate to $\mathrm{p} 53$ activation and/or stabilization. ${ }^{42}$ The fact that $\mathrm{TNF} \alpha$ treatment led to an accumulation of a transcriptional inactive form of p53 prompts us to analyze the phosphorylation state of p53 in TNF $\alpha$-treated cells. Adriamycin treatment that activates p53 was used as a positive control. p53 phosphorylation was revealed by Western blot using antibodies directed against phosphorylated Ser-15, -20 or -392 . As expected, the adriamycin treatment induced p53 phosphorylation at these three sites (Figure 7, panel B1). Phosphorylation at Ser-20 and Ser-392 occurred earlier (1-2 $\mathrm{h}$ after adding adriamycin) than phosphorylation at Ser-15, which was detectable only $8 \mathrm{~h}$ after the addition of adriamycin to the culture medium. In contrast, no phosphorylated form of p53 was revealed in TNF $\alpha$-treated MCF-7 cells (Figure 7, panel B2). As already mentioned, the p53 concentration is lower in TNF $\alpha$ - than in adriamycin-treated cells (compare the intensity of the bands revealed by DO-7 in panel $\mathrm{B} 1$ and $\mathrm{B} 2$ ). To ensure that no detection of p53 phosphorylated forms in $\mathrm{TNF} \alpha$-treated cellular extracts was not a bias imputable to the limit of antibody sensitivity, Western blot were performed by loading an equivalent amount of whole p53 protein. Results are presented in Figure 7 for a $16 \mathrm{~h}$ treatment with either adriamycin (panel B1, lane $7 b$ ) or $\operatorname{TNF} \alpha$ (B2, lane 7b). Although the DO-7-band intensity was comparable in both cases, again there was no specific band revealed by antibody directed against the phosphorylated forms of p53 in TNF $\alpha$ treated cell extracts. We conclude that, in contrast to adriamycin treatment, TNF $\alpha$ leads to accumulation of a p53 protein non-phosphorylated at position 15, 20 and 392.

\section{Concomitant increase of p53 protein and mRNA levels in MCF-7, in response to TNF $\alpha$}

The promoter sequences of the p53 gene contains binding elements for transcription factors that may regulate expression in response to defined stimuli, including motifs for AP1, NF- $\kappa$ B and Myc/Max/USF. ${ }^{43}$ The fact that TNF $\alpha$ activated NF$\kappa \mathrm{B}$ makes p53 gene a good candidate to be transcriptionally regulated by $\mathrm{TNF} \alpha$. We then quantified, at different times following the addition of $\mathrm{TNF} \alpha$ to the culture medium, the 
relative levels of p53 mRNA by real-time detection of PCR products. The level of p53 protein was estimated in parallel cultures by ELISA assay as described in experimental procedures. Results presented in Figure 8 show that TNF $\alpha$ had doubled the level of $p 53$ mRNA $16 \mathrm{~h}$ after the addition of TNF $\alpha$. Interestingly, the time-courses of p53 mRNA and protein accumulation are comparable in terms of kinetics and magnitude. This observation suggests that TNF $\alpha$-induced accumulation of p53 protein results from a higher rate of transcription rather than from a stabilization of the protein.

All taken together, these results demonstrate that TNF $\alpha$ induces the accumulation of an inactive form of p53 by regulating the p53 transcription level.

\section{Discussion}

In this paper, we show that TNF $\alpha$ induces the expression of both $p 53$ and $p 21 /$ Waf1 in MCF-7 cell line. We provide evidence that NF- $\kappa$ B but not $p 53$ is involved in the regulation of $p 21 /$ Waf1 by showing that NF- $k B$ but not $p 53$ inactivation impairs TNF $\alpha$-induced stimulation of $p 21 /$ Waf1 expression. This led us to demonstrate that TNF $\alpha$ induces the accumulation of an inactive form of p53 unable to bind specifically to DNA and to activate the expression of its target genes. Consistent with this assumption, we report that Ser-15, Ser20 , and Ser-392 are not phosphorylated in response to TNF $\alpha$. It is well documented that phosphorylation at Ser-15 and Ser392 up-regulates the p53's transcriptional activity. ${ }^{44}$ The notion that p53 accumulation could be dissociated from its activation has already been proposed. Chernov et al. ${ }^{18}$ showed that PKC inhibitors induce an increase in p53 lifetime without inducing p53 activation. Tryptic digestion of stabilized protein shows that although PKC inhibitor decreases the overall level of p53 phosphorylation, this treatment leads to the appearance of a new set of phosphopeptides, leading the authors to propose that accumulation and activation of p53 could result from distinct phosphorylation events.

In our cellular model, both p53 mRNA and protein levels increased in parallel, strongly suggesting that the rate of p53 gene transcription could account for the accumulation of p53 protein. Indeed the p53 promoter contains a functional NF- $\kappa \mathrm{B}$ site ${ }^{43}$ supporting the hypothesis that the increase level of p53 mRNA could arise from the TNF $\alpha$ mediated NF- $\kappa \mathrm{B}$ activation. In this line of evidence, it was previously reported that p53 gene expression is activated through NF- $\kappa$ B after Benzo(a)pyrene treatment. ${ }^{15}$

The idea that p53 accumulation results from a higher transcription rate rather than from the protein stabilization is emphasised by the fact that TNF $\alpha$ did not induce p53 phosphorylation at Ser-20. Indeed, phosphorylation at Ser20 has been shown to inhibit p53 interaction with the ubiquitin-ligase MDM2, preventing p53 degradation by the proteasome pathway and thereby promoting p53 stabilization. 50

Some papers describe the existence of an emerging $\mathrm{PKR} / \mathrm{p} 53$ pathway involved in TNF-induced apoptosis (reviewed $\mathrm{in}^{45}$ ). It has been demonstrated that the TNF $\alpha$ inducible kinase PKR can phosphorylate p53 in vitro at serine 392. ${ }^{46}$ Phosphorylation of serine 392 has been shown, in vitro, to convert p53 to an active form, ${ }^{47}$ suggesting that $T N F \alpha$ could activate p53 through PKR. Our results argue against this interpretation since we did not detect p53 modification at serine 392 in TNF $\alpha$-treated cells. Alternatively, PKR, which has been reported to activate NF- $\kappa$ B (reviewed $\mathrm{in}^{48}$ ), could participate in the increase of p53 gene expression. In support of this notion, it was demonstrated that p53 mRNA expression level is increased in PKR-overexpressing cells. ${ }^{49}$

On the other hand, NF- $\kappa \mathrm{B}$ inactivation, which diminishes the expression of p21/Waf1, has no effect on TNF $\alpha$ dependent G1-arrest. This fact would imply that p21/Waf1 is not involved in the G1 arrest induced by TNF $\alpha$. We can not exclude, however, the possibility that a very low remaining expression of $p 21 /$ Waf1 could account for the G1-arrest identified in TNF $\alpha$-treated MAD-1904 cells. In different cellular models, other investigators have found that p21/Waf1 is not required to induce G1-arrest in response to TNF $\alpha$. Shiohara et al. ${ }^{51}$ have shown that overexpression of p21/Waf1 antisense in ME-180 cells does not abrogate TNF $\alpha$-dependent G1-growth arrest. Additionally, Nalca and Rangnekar ${ }^{52}$ have demonstrated that interleukin-1 (IL-1), another cytokine promoting cytostatic effects, induces p53 and p21/Waf1 expression. However, and in agreement with our results with TNF $\alpha$, cells in which $p 53$ and p21/Waf1 have been switched off are still arrested in the G1-phase following IL-1 incubation. ${ }^{52}$ These results raise the question of the pathway by which cytokines such as TNF $\alpha$ or IL-1, could induce G1-arrest. In preliminary experiments, we showed that the product of the retinoblastoma gene $(R b)$ is under-phosphorylated in response to TNF $\alpha$ (data not shown). $\mathrm{Rb}$ has been implicated in the regulation of the cell cycle through its interaction with the transcription factor E2F. Dephosphorylated Rb interacts with E2F, leading to functional inhibition of this protein that is essential for cellcycle progression (reviewed $\mathrm{in}^{53}$ ). In the hypothesis of an inhibition of $\mathrm{Rb}$ phosphorylation by TNF $\alpha, \mathrm{G} 1$ arrest would depend on the maintenance of hypo-phosphorylated forms of $\mathrm{Rb}$ rather than on p21/Waf1 overexpression or p53 activation.

Although TNF $\alpha$-induced p21/Waf1 accumulation seems not to be involved in $\mathrm{G} 1$ arrest, it might play an antiapoptotic role against TNF $\alpha$-induced apoptosis. Indeed, it has been shown that expression of an antisense of p21/ Waf1 sensitizes MCF-7 cells to TNF $\alpha$-dependent apoptosis. $^{24}$ Consistent with this, cytoplasmic accumulation of p21/Waf1 observed during monocytic differentiation is concomitant with a resistance to various apoptotic stimuli including TNF $\alpha{ }^{54}$ Therefore, it will be interesting to analyze the MCF-7 sub-cellular localization of p21/Waf1 in response to $\mathrm{TNF} \alpha$.

In conclusion, we show that TNF $\alpha$ stimulates the expression of both $p 21 /$ Waf1 and p53, in MCF-7 cells, and that the TNF $\alpha$-related stimulation of $p 21 /$ Waf1 is dependent on NF- $\kappa \mathrm{B}$ activation. The accumulation of p53 that arises from an increase of p53 gene transcription, could also depend on TNF $\alpha$-mediated activation of NF- $\kappa$ B. Although TNF $\alpha$ leads to the accumulation of a transcriptional inactive form of $p 53$, it cannot be excluded that p53 accumulation could be involved in TNF $\alpha$-dependent induction of apoptosis. Indeed, it has been reported that p53 can 
induce apoptosis independently of its transactivation properties (reviewed $\mathrm{in}^{55}$ ). Moreover, some published results suggested an implication of $\mathrm{p} 53$ in TNF $\alpha$-dependent apoptosis. $^{35,56}$ We are presently analyzing the possible relationship between p53 accumulation and TNF $\alpha$-induced apoptosis.

\section{Materials and Methods}

\section{Cells and treatment}

The cells U-2 OS (derived from a human osteosarcoma), MCF-7 (derived from a human breast carcinoma) and Hep G2 (derived from a human hepatocellular carcinoma) express wt-p53. MCF-7/MAD1904 cells, expressing $I_{\kappa} \mathrm{B} \alpha$, the dominant negative of NF- $\kappa \mathrm{B}^{35}$ and MCF-7/ E6, expressing HPV16/E6 protein $^{26}$ were a gift from S Chouaib. MCF7/DD-TO cell lines were derived from MCF-7 using the tetracyclineregulated mammalian expression ( $\mathrm{T}-\mathrm{Rex}^{\mathrm{TM}}$ ) system from Invitrogen. $\mathrm{T}-\mathrm{Rex}^{\mathrm{TM}}$ System uses regulatory elements from the E. coli Tn10encoded tetracycline (Tet) resistance operon. In this system, expression of the gene of interest is repressed in the absence and induced in the presence of tetracycline. MCF-7 cells were first stably transfected with pcDNA6/TR, which encodes the Tet repressor (TetR) under the control of the human CMV promoter. The TetR-expressing cell line was then stably transfected with pDDm-TO, a tetracycline inducible expression vector obtained by inserting the sequence that encodes the mouse p53DD truncated protein, into the Invitrogen vector, $\mathrm{pcDNA} 4 / \mathrm{TO} / \mathrm{B}$. The $\mathrm{p53DD}$ truncated protein includes the mouse p53-amino acid residues $1-14$ and $302-390 .{ }^{57}$ Transfections were performed according to the manufacturer's protocol.

All cells were maintained at $37^{\circ} \mathrm{C}$ in DMEM containing $10 \%$ foetal calf serum (FCS). MCF-7/MAD1904 and MCF-7/E6 cell lines were cultured in the presence of $0.2 \mathrm{mg} / \mathrm{ml}$ of geneticin (Gibco BRL). The p53DD protein expression was induced by adding tetracycline to the medium $(1 \mu \mathrm{g} / \mathrm{ml})$. All the treatments were performed $48 \mathrm{~h}$ after plating $\left(3.10^{6}\right.$ cells per $10 \mathrm{~cm}$ Petri dish), except otherwise indicated. TNF $\alpha$ (Sigma) was added to a final concentration of $10 \mathrm{ng} / \mathrm{ml}$. Sodium salicylate was added at the indicated concentration for $30 \mathrm{~min}$ before adding TNF $\alpha(10 \mathrm{ng} / \mathrm{ml})$, and incubated for an additional $16 \mathrm{~h}$. Adriamycin $(10 \mu \mathrm{g} / \mathrm{ml}$, Sigma) was added for $16 \mathrm{~h}$. The cells were exposed to $\gamma$ irradiation at a dose of $6 \mathrm{~Gy}$ and a dose rate of $2.0 \mathrm{~Gy} /$ min, using a ${ }^{137} \mathrm{Cs}$ source (IBL 637 apparatus, Cisbio International).

\section{Northern blot}

Northern-blot analysis was performed as described. ${ }^{28}$ Preparation of the probes has been described. ${ }^{58}$

\section{Western blot}

Western blots were performed as described. ${ }^{58}$ Whole p53 protein was detected using DO-7 or PAb122 supernatant hybridomas, the phosphorylated forms using anti-phosphop53 Ser-15, -20, and -392 from Cell Signaling technology. The p21/Waf1 protein was revealed with the anti-p21/Waf1 (Ab1) from Calbiochem.

\section{Cell fractionation}

Cells were scraped, washed and lysed in buffer $\mathrm{A}$ (20 mM HEPES, $\mathrm{pH}$ 7.6, $10 \mathrm{mM} \mathrm{NaCl}, 1.5 \mathrm{mM} \mathrm{MgCl}_{2}, 0.2 \mathrm{mM}$ EDTA, $1 \mathrm{mM}$ DTT, $20 \%$ glycerol, $4 \mathrm{mM}$ Pefabloc) containing $0.1 \% \mathrm{NP}-40$. The lysate was centrifuged for $5 \mathrm{~min}$ at $500 \times \mathrm{g}$. Supernatant was collected and centrifuged at $100000 \times g$ for $1 \mathrm{~h}$ at $4^{\circ} \mathrm{C}$. Soluble material which represents the cytosol fraction, was conserved at $-80^{\circ} \mathrm{C}$, while the pellet was resuspended in ice-cold sucrose buffer I (320 mM sucrose, $3 \mathrm{mM} \mathrm{CaCl}_{2}, 2 \mathrm{mM} \mathrm{MgCl}$, $0.1 \mathrm{mM}$ EDTA, $10 \mathrm{mM}$ Tris-base, $\mathrm{pH}$ 8.0, $1 \mathrm{mM}$ DTT, $0.1 \% \mathrm{NP}-40$ ). The resuspended pellet was loaded on a cushion of sucrose buffer II ( $2 \mathrm{mM}$ sucrose, $5 \mathrm{mM} \mathrm{MgCl}_{2}, 0.1 \mathrm{mM}$ EDTA, $10 \mathrm{mM}$ Tris-base, pH 8.0, $1 \mathrm{mM}$ DTT) and centrifuged at $30000 \times g$ at $4{ }^{\circ} \mathrm{C}$ for $45 \mathrm{~min}$. The pellet (nucleus) was washed twice in buffer $A$ and nuclear proteins were extracted using the same buffer containing additionally $0.5 \mathrm{M} \mathrm{NaCl}$. Then, nuclear and cytosol fraction (30 $\mu \mathrm{g}$ of total protein) were separated on a $10 \%$ gel SDS-PAGE and p53 was detected by Western blot.

\section{EMSA}

Nuclear extracts were prepared as described. ${ }^{58}$ For p53 DNA binding analysis, nuclear extract (10 $\mu \mathrm{g}$ of total protein) was incubated with $0.4 \mathrm{ng}$ of ${ }^{32} \mathrm{P}$-labelled self-renatured palindromic probe [TCGACGGACATGCCCGGGCATGTCC] (the underlined nucleotides correspond to the consensus sequence). Complexes were resolved on a $4 \%$ native acrylamide gel or on a PhastGel gradient 4-15\% (Amersham Pharmacia biotech) as described. ${ }^{58}$ For Sp1 and NF- $\kappa$ B DNA binding analysis, nuclear extract (5 $\mu \mathrm{g}$ of total protein) was incubated with Sp1 and NF- $\kappa \mathrm{B}-{ }^{32} \mathrm{P}$-labelled consensus probes, and complexes were separated on a $4 \%$ or $6 \%$ non-denaturing acrylamide gel, respectively. $\mathrm{Sp} 1$ and NF- $\kappa \mathrm{B}$ probes were purchased from Promega.

\section{ELISA}

Cells were scraped, washed twice with ice-cold PBS and lysed for $30 \mathrm{~min}$ at $4^{\circ} \mathrm{C}$ in buffer containing $50 \mathrm{mM}$ Tris-base ( $\mathrm{pH} \mathrm{8.0)}, 150 \mathrm{mM}$ $\mathrm{NaCl}, 5 \mathrm{mM}$ EDTA, 1\% NP40 and $1 \mathrm{mM}$ Pefabloc (Boehringer Mannheim). Solubilized extracts were collected after centrifugation for $15 \mathrm{~min}$ at $10000 \times \mathrm{g}$. Total protein concentration was determined by the Bradford assay (Biorad Protein Assay). The p53 and p21/Waf1 protein concentrations in extract were estimated using the 'p53 pan ELISA' kit (Roche Molecular Biochemicals) and the 'Waf1 ELISA' kit (Oncogene Research Product), respectively.

\section{Cell cytometry analysis}

MCF-7 cells were collected, washed with PBS and then fixed in 70\% ethanol. After $16 \mathrm{~h}$ at $-20^{\circ} \mathrm{C}$, cells were washed with PBS and then incubated for $30 \mathrm{~min}$ at $37^{\circ} \mathrm{C}$ in $0.5 \mathrm{ml}$ of PBS containing $50 \mu \mathrm{g} / \mathrm{ml}$ propidium iodide and $50 \mu \mathrm{g} / \mathrm{ml}$ RNAse A. Cell DNA content was evaluated by flow cytometry using a FacScan (Becton Dickinson).

\section{Luciferase assay}

Luciferase assays were performed as previously reported using the pE1B-hWaf1 plasmid, which contains the human Waf1-p53 responsive element cloned upstream the luciferase gene. ${ }^{59}$

\section{Real-time quantitation mRNA}

p53 mRNA was quantified using the TaqMan apparatus (Perkin Elmer Biosystems), while p21/Waf1 and Ddb2 mRNAs were quantified using Lightcycler apparatus (Roche Molecular Biochemicals).

For p53 quantification, cDNA synthesis was performed in a volume of $20 \mu \mathrm{l}$ using TaqMan reverse transcription reagents (Perkin Elmer Biosystems, Foster City, USA), as previously described. ${ }^{60}$ For the $\beta$ - 
actin gene, the sense primer [ACCGAGGCCCCCCTG] and the probe [VIC-CCCAAGGCCAACCGCGAGAAACAGCCTGGATAGCAACGTA$\mathrm{CA}$ ] were located in exon 3 and the antisense primer [ACAGCCTGGATAGCAACGTACA] in exon 4. For the p53 gene, the sense primer (CCCAGCCAAAGAAGAAACCA) was in exon 9, the probe [6FAMCCCTTCAGATCCGTGGGCGTGA-TAMRA] at the junction between exon 9 and 10 and the antisense primer in exon 10 [CTCGGAACATCTCGAAGCG]. PCR was performed as previously described. ${ }^{60}$ The use of VIC and 6-FAM reporter dye on the $\beta$-actin and p53 probes, respectively, allowed quantification from a multiplex PCR reactions. Results are normalized to $\beta$-actin.

For p21/Waf1 and Ddb2 mRNA quantification, cDNA synthesis was performed using oligo dT (Sigma) and AMV reverse transcriptase as described by the manufacturer (Promega). Real-time quantitative PCR was done using the 'FastStart DNA Master SYBR Green' kit (Roche Molecular Biochemical). PCR were performed with the oligonucleotide pairs [GGACCTGTCACTGTCTTGTA]/[GGCTTCCTCTTGGAGAAGAT] for p21/Waf1; [GAACAACTAGGCTGCAAGAC]/[ATTCGGCTACTAGCAGACAC] for Ddb2 and [AGCTCACTGGCATGGCCTTC] [ACGCCTGCTTCACCACCTTC] for GAPDH. Results are normalized to GAPDH.

\section{Acknowledgements}

We are grateful to S Chouaib for providing MCF-7/MAD1904 and MCF-7/ E6 cell lines and to D Lane for providing DO-7 hybridoma cells. We wish to thank P May and JC Lelong for critical reading of the manuscript. This work was supported by grant FMRX-CT97-0153 from the European Commission and by a grant from EDF. $P$ Drané was supported by a fellowship from CEA and from EDF.

\section{References}

1. Sugarman BJ, Aggarwal BB, Hass PE, Figari IS, Palladino Jr MA and Shepard HM (1985) Recombinant human tumor necrosis factor-alpha: effects on proliferation of normal and transformed cells in vitro. Science 230: 943-945

2. Aggarwal BB and Natarajan K (1996) Tumor necrosis factors: developments during the last decade. Eur Cytokine Netw. 7: 93-124

3. Vilcek J, Palombella VJ, Henriksen-DeStefano D, Swenson C, Feinman R, Hirai $\mathrm{M}$ and Tsujimoto M (1986) Fibroblast growth enhancing activity of tumor necrosis factor and its relationship to other polypeptide growth factors. J. Exp. Med. 163: 632-643

4. Jeoung Di, Tang B and Sonenberg M (1995) Effects of Tumor Necrosis Factoralpha on Antimitogenicity and Cell Cycle-related Proteins in MCF-7 Cells. J. Biol. Chem. 270: $18367-18373$

5. Ashkenazi A and Dixit VM (1998) Death receptors: signaling and modulation. Science 281: 1305-1308

6. Muzio M, Chinnaiyan AM, Kischkel FC, O'Rourke K, Shevchenko A, Ni J, Scaffidi C, Bretz JD, Zhang M, Gentz R, Mann M, Krammer PH, Peter ME and Dixit VM (1996) FLICE, a novel FADD-homologous ICE/CED-3-like protease, is recruited to the CD95 (Fas/APO-1) death-inducing signaling complex. Cell 85: 817-827

7. Boldin MP, Goncharov TM, Goltsev YV and Wallach D (1996) Involvement of $\mathrm{MACH}$, a novel MORT1/FADD-interacting protease, in Fas/APO-1 and TNF receptor-induced cell death. Cell 85: 803-815

8. Hsu H, Shu HB, Pan MG and Goeddel DV (1996) TRADD-TRAF2 and TRADDFADD interactions define two distinct TNF receptor 1 signal transduction pathways. Cell 84: 299-308

9. Liu ZG, Hsu H, Goeddel DV and Karin M (1996) Dissection of TNF receptor 1 effector functions: JNK activation is not linked to apoptosis while NF-kappaB activation prevents cell death. Cell 87: 565-576

10. Wang CY, Mayo MW and Baldwin AS (1996) TNF- and cancer therapy-induced apoptosis: potentiation by inhibition of NF-kappaB. Science 274: 784-787
11. Beg AA and Baltimore D (1996) An essential role for NF-kappaB in preventing TNF-alpha-induced cell death. Science 274: 782-784

12. Barkett M and Gilmore TD (1999) Control of apoptosis by Rel/NF-kappaB transcription factors. Oncogene 18: 6910-6924

13. Hellin AC, Calmant P, Gielen J, Bours V and Merville MP (1998) Nuclear factor kappa B-dependent regulation of p53 gene expression induced by daunomycin genotoxic drug. Oncogene 16: 1187-1195

14. Kirch HC, Flaswinkel S, Rumpf H, Brockmann D and Esche H (1999) Expression of human p53 requires synergistic activation of transcription from the p53 promoter by AP-1, NF-kappaB and Myc/Max. Oncogene 18: 2728-2738

15. Pei XH, Nakanishi Y, Takayama K, Bai F and Hara N (1999) Benzo[a]pyrene activates the human p53 gene through induction of nuclear factor kappa $B$ activity. J. Biol. Chem. 274: 35240-35246

16. May $P$ and May $E$ (1999) Twenty years of $p 53$ research: structural and functional aspects of the p53 protein. Oncogene 18: 7621-7636

17. Appella E and Anderson CW (2000) Signaling to p53: breaking the posttranslational modification code. Pathol. Biol. 48: 227-245

18. Chernov MV, Ramana CV, Adler VV and Stark GR (1998) Stabilization and activation of p53 are regulated independently by different phosphorylation events. Proc. Natl. Acad. Sci. USA 95: 2284-2289

19. Sionov RV and Haupt $Y$ (1999) The cellular response to p53: the decision between life and death. Oncogene 18: 6145-6157

20. Gartel AL and Tyner AL (1999) Transcriptional regulation of the p21((WAF1/ CIP1)) gene. Exp. Cell. Res. 246: 280-289

21. Bouvard V, Zaitchouk T, Vacher M, Duthu A, Canivet M, Choisy-Rossi C, Nieruchalski M and May E (2000) Tissue and cell-specific expression of the p53target genes: bax, fas, mdm2 and waf1/p21, before and following ionising irradiation in mice. Oncogene 19: 649-660

22. Kobayashi N, Takada Y, Hachiya M, Ando K, Nakajima N and Akashi M (2000) TNF-alpha induced p21 (waf1) but not bax in colon cancer cells widr with mutated p53: important role of protein stabilization. Cytokine 12: 1745-1754

23. Pusztai L, Lewis CE and Mcgee JO (1993) Growth arrest of the breast cancer cell line, T47D, by TNF alpha; cell cycle specificity and signal transduction. Br. J. Cancer 67: 290-296

24. Jiang $Y$ and Porter AG (1998) Prevention of tumor necrosis factor (TNF)mediated induction of $\mathrm{p} 21 \mathrm{WAF} 1 / \mathrm{CIP} 1$ sensitizes MCF-7 carcinoma cells to TNFinduced apoptosis. Biochem. Biophys. Res. Commun. 245: 691-697

25. Sherr CJ and Roberts JM (1995) Inhibitors of mammalian G(1) cyclin-dependent kinases. Gene Develop. 9: 1149-1163

26. Fan SJ, Smith ML, Rivet DJ, Duba D, Zhan QM, Kohn KW, Fornace AJ and Oconnor PM (1995) Disruption of p53 function sensitizes breast cancer MCF-7 cells to cisplatin and pentoxifylline. Cancer Res. 55: 1649-1654

27. Scheffner M, Huibregtse JM, Vierstra RD and Howley PM (1993) The HPV-16 E6 and E6-AP complex functions as a ubiquitin-protein ligase in the ubiquitination of p53. Cell 75: 495-505

28. Deguin-Chambon V, Vacher M, Jullien M, May E and Bourdon JC (2000) Direct transactivation of c-Ha-Ras gene by p53 - Evidence for its involvement in p53 transactivation activity and p53-mediated apoptosis. Oncogene 19:5831-5841

29. Javelaud D, Wietzerbin J, Delattre $O$ and Besancon $F(2000)$ Induction of p21Waf1/Cip1 by TNFalpha requires NF-kappaB activity and antagonizes apoptosis in Ewing tumor cells. Oncogene 19:61-68

30. Cai Z, Korner M, Tarantino N and Chouaib S (1997) IkappaB alpha overexpression in human breast carcinoma MCF7 cells inhibits nuclear factorkappaBactivation but not tumor necrosis factor-alpha-induced apoptosis. J. Biol. Chem. 272: 96-101

31. Traenckner EB, Pahl HL, Henkel T, Schmidt KN, Wilk S and Baeuerle PA (1995) Phosphorylation of human I kappa B-alpha on serines 32 and 36 controls I kappa $\mathrm{B}$-alpha proteolysis and NF-kappa B activation in response to diverse stimuli. EMBO J. 14: 2876-2883

32. Jones PL, Ping D and Boss JM (1997) Tumor necrosis factor alpha and interleukin-1beta regulate the murine manganese superoxide dismutase gene through a commplex intronic enhancer involving C/EBP-beta and NF-kappaB. Mol. Cell. Biol. 17: 6970-6981

33. Xu Y, Kiningham KK, Devalaraja MN, Yeh CC, Majima H, Kasarskis EJ and St Clair DK (1999) An intronic NF-kappaB element is essential for induction of the human manganese superoxide dismutase gene by tumor necrosis factor-alpha and interleukin-1 beta. DNA Cell. Biol. 18: 709-722 
34. Grilli M, Pizzi M, Memo M and Spano P (1996) Neuroprotection by aspirin and sodium salicylate through blockade of NF-kappaB activation. Science 274 : $1383-1385$

35. Cai ZZ, Capoulade C, Moyretlalle C, AmorGueret M, Feunteun J, Larsen AK, Bressacdepaillerets B and Chouaib S (1997) Resistance of MCF7 human breast carcinoma cells to TNF-induced cell death is associated with loss of p53 function. Oncogene 15: 2817-2826

36. Hwang BJ, Ford JM, Hanawalt PC and Chu G (1999) Expression of the p58 xeroderma pigmentosum gene is p53-dependent and is involved in global genomic repair. Proc. Natl. Acad. Sci. USA 96: 424-428

37. Das KC and White CW (1997) Activation of NF-kappaB by antineoplastic agents. Role of protein kinase C. J. Biol. Chem. 272: 14914-14920

38. Shaulsky G, Goldfinger N, Peled A and Rotter V (1991) Involvement of wild-type p53 in pre-B-cell differentiation in vitro. Proc. Natl. Acad. Sci. USA 88: $8982-$ 8986

39. TakahashiK and Suzuki K(1994) DNA Synthesis-Associated Nuclear Exclusion of p53 in Normal Human BreastEpithelial Cells in Culture. Oncogene 9: 183-188

40. David-Pfeuty T, Chakrani F, Ory K and Nouvian-Dooghe Y (1996) Cell cycledependent regulation of nuclear p53 traffic occurs in one subclass of human tumor cells and in untransformed cells. Cell Growth Differ. 7: 1211-1225

41. Ryan KM, Phillips AC and Vousden KH (2001) Regulation and function of the p53 tumor suppressor protein. Current Opinion in Cell Biology 13: 332-337

42. Appella E and Anderson CW (2001) Post-translational modifications and activation of $p 53$ by genotoxic stresses. Eur. J. Biochem. 268: 2764-2772

43. Wu HY and Lozano G (1994) NF-kappaB activation of p53 - A potential mechanism for suppressing cell growth in response to stress. J. Biol. Chem. 269: 20067-20074

44. Meek DW (1999) Mechanisms of switching on p53: a role for covalent modification? Oncogene 18: 7666-7675

45. Williams BR (1999) PKR; a sentinel kinase for cellular stress. Oncogene 18: $6112-6120$

46. Cuddihy AR, Wong AH, Tam NW, Li S and Koromilas AE (1999) The doublestranded RNA activated protein kinase PKR physically associates with the tumor suppressor p53 protein and phosphorylates human p53 on serine 392 in vitro. Oncogene 18: 2690-2702

47. Hupp TR, Meek DW, Midgley CA and Lane DP (1992) Regulation of the specific DNA binding function of $p 53$. Cell $71: 875-886$
48. Pahl HL (1999) Activators and target genes of Rel/NF-kappaB transcription factors. Oncogene 18: 6853-6866

49. Yeung MC and Lau AS (1998) Tumor suppressor p53 as a component of the tumor necrosis factor-induced, protein kinase PKR-mediated apoptotic pathway in human promonocytic U937 cells. J. Biol. Chem. 273: 25198-25202

50. Craig AL, Burch L, Vojtesek B, Mikutowska J, Thompson A and Hupp TR (1999) Novel phosphorylation sites of human tumour suppressor protein p53 at Ser20 and Thr18 that disrupt the binding of $\mathrm{mdm} 2$ (mouse double minute 2) protein are modified in human cancers. Biochem. J. 342 (Pt 1): 133-141

51. Shiohara M, Gombart AF, Berman JD, Koike K, Komiyama A and Koeffler HP (1997) Cytostatic effect of TNFalpha on cancer cells is independent of p21WAF1. Oncogene 15: 1605-1609

52. Nalca A and Rangnekar VM (1998) The G1-phase growth-arresting action of interleukin- 1 is independent of p53 and p21/Waf1 function. J. Biol. Chem. 273 30517-30523

53. Harbour JW and Dean DC (2000) The Rb/E2F pathway: expanding roles and emerging paradigms. Genes Dev. 14: 2393-2409

54. Asada M, Yamada T, Ichijo H, Delia D, Miyazono K, Fukumuro K and Mizutani S (1999) Apoptosis inhibitory activity of cytoplasmic p21(Cip1/WAF1) in monocytic differentiation. EMBO J. 18: 1223-1234

55. Gottlieb TM and Oren M (1998) p53 and apoptosis. Semin. Cancer Biol. 8: 359 368

56. Rokhlin OW, Gudkov AV, Kwek S, Glover RA, Gewies AS and Cohen MB (2000) p53 is involved in tumor necrosis factor-alpha-induced apoptosis in the human prostatic carcinoma cell line LNCaP. Oncogene 19: 1959-1968

57. Shaulian E, Haviv I, ShaulY and Oren M (1995) Transcriptional repression by the C-terminal domain of p53. Oncogene 10: 671-680

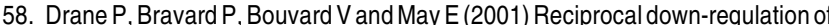
p53 and SOD2 gene expression - implication in p53 mediated apoptosis. Oncogene 20: 430-439

59. Munsch D, Watanabe-Fukunaga R, Bourdon JC, Nagata S, May E, YonishRouach E and Reisdorf P (2000) Human and mouse Fas (APO-1/CD95) death receptor genes each contain a p53-responsive element that is activated by p53 mutants unable to induce apoptosis. J. Biol. Chem. 275: 3867-3872

60. Saffroy R, Lemoine A, Brezillon P, Frenoy N, Delmas B, GoldschmidtE, Souleau $B$, Nedellec $G$ and Debuire B (2000) Real-time quantitation of bcr-abl transcripts in haematological malignancies. Eur. J. Haematol. 65: 258-266 